International Journal of Heritage, Tourism and Hospitality Vol. (12), No. (3/2)

Special issue on papers of the $11^{\text {th }}$ ICTH (2018) organized by Faculty of Tourism and Hotels, Fayoum University

Corporate Social Responsibility in Quick Service Restaurants: An exploratory study of social responsibility activities applied in global and local restaurant chains in Egypt

\author{
Hany A. Kozmal \\ High Institute for Tourism and Hotel \\ Amira H. Abd El-Monem \\ Management - Luxor (Egoth) \\ Faculty of Tourism and Hotel \\ Management, Helwan University
}

\begin{abstract}
Ordinarily business is aimed at maximizing their profits, sometimes disregarding its impact on the environment and the society in which they are located. Many researchers have confirmed that Corporate Social Responsibility (CSR) is an integral part of the business strategy and corporate identity. Because management and operating systems of Quick Service Restaurants (QSRs) differ from one chain to another, it was necessary to identify their CSR programs and activities. For that, this research aims at understanding CSR by identifying the social responsibility activities and programs implemented in Global Chain Restaurants and local Chain Restaurants. This aim is based on the assumption that unfair CSR is divided based on the size of the company. Quantitative approach was used. A questionnaire was designed to fulfill the research objectives. It was distributed to QSR's managers in Egypt such as McDonalds, KFC, Burger King as global restaurant chains, and Mo'men, Cook Door as local ones. The overall results indicated that CSR is a leading principle of top management at both of the global and local restaurant chains. Their programs are characterized by strategic planning that seeks to achieve both society and environment service and the goals of the operation.
\end{abstract} keywords: CSR, QSRs, Global restaurant chains, Local restaurant chains, Society, Environment.

\title{
introduction
}

The hospitality industry has recently been recognized for its growing interest in corporate social responsibility (CSR). This stems from its interest in improving its position among its competitors in various performances, not just financial performance (Claver-Cortes et al., 2007; Kang et al., 2010; Lee and Park, 2009; Garay and Font, 2012).

CSR is one of the significant challenges for any organization. It is linked to many relationships and variables both inside and outside the organization. Social responsibility is a center of interest in developed societies, especially with increased competition in the existing environment (Lee, 2008). The organizations' awareness of the importance of balancing their profitability and social objectives is a critical factor in their growth and long-term endurance (Murillo and Martinek, 2009; Mishra and Suar, 2010).

The food and fast food sector, especially in the densely populated major cities, is developing rapidly in various economic and social conditions, prompting many observers to evaluate the fast-food and restaurant market as one of the fastest growing markets in the world (Warsi and Nisa, 2017).

\section{The Research Aim}

This study lies in dealing with the CSR practices in QSRs. It would like to provide restaurants managers a clear picture about the CSR, and to explore the gap between the global and local restaurants chains. The purpose of the study is to examine the similarities and differences between CSR programs applied in both global and local restaurant chains. To achieve the aim of the study, it has four objectives: Undertaking a review of literature on the social responsibility and QSRs, investigating managers' perceptions towards the 
International Journal of Heritage, Tourism and Hospitality Vol. (12), No. (3/2)

Special issue on papers of the $11^{\text {th }}$ ICTH (2018) organized by Faculty of Tourism and Hotels, Fayoum University

CSR programs applied in their chains and its importance, developing a suggested practice gap model, and establishing a set of recommendations and suggestions in order to improve CSR in QSRs in Egypt.

\section{The Research Problem}

The research problem is to examine the similarities and differences between CSR programs applied in both global and local restaurant chains in Egypt through the following points: Identifying the reasons of increasing the CSR on QSRs. Studying the points that restaurants need to be strengthened to improve CSR, are there any statistically significant relations between the CSR in accordance to quick service restaurant chains in Egypt?

\section{The Study Hypotheses}

Based on the above discussion the following two hypotheses were proposed to test the conceptual model of CSR and its impact on the quick service restaurant:

Hypothesis 1: "There is a statistically significant difference between the mean scores of ranked average of the impact of CSR and that of the kind of the quick service restaurant chain (Global - Local).

Hypothesis 2: chain differences positively affect CSR impact

\section{Literature Review}

CSR is progressively becoming a widespread business perception in developed economies. For more than 60 years, many different definitions of CSR have emerged. However, the concept is still complex and unclear for those interested in this issue (Carroll and Shabana, 2010; Yin, 2017).

Park and Levy (2014) stated that, the origin of CSR can be recognized to at least three sources, which pointed out the long history of this issue: Dodd's (1932) argument for firms' responsibility toward society beyond shareholders (Cochran, 2007), Bowen's (1953) book 'Social Responsibilities of Businessman' (Carroll, 1999) whom Carroll (1999) called, the "Father of CSR", or Boulding's general systems theory (1956) in respects to CSR dimensions (cited in Wood, 2010).

Amaeshi et al., (2007) agreed with Sila and, Ceka, (2017) on that CSR can be broadly defined as "an organization's commitment to operate in an economically and environmentally sustainable manner while recognizing the interests of its stakeholders". By analyzing the other definitions, it became obvious that most authors were referring to several of the same dimensions of CSR. Therefore, the phrases that referred to the same dimension were grouped together. This process identified five dimension, which were named to reflect the content of the phrases. Table 1 shows the five dimensions and examples of phrases that refer to the dimensions as presented by Dahlsrud (2008).

Table 1: the five dimensions, how the coding scheme was applied and example phrase

\begin{tabular}{|c|c|l|}
\hline Dimensions & $\begin{array}{c}\text { Example of } \\
\text { dimension }\end{array}$ & \multicolumn{1}{|c|}{ Example phrases } \\
\hline $\begin{array}{c}\text { The } \\
\text { environmental } \\
\text { dimension }\end{array}$ & $\begin{array}{c}\text { The natural } \\
\text { environment }\end{array}$ & $\begin{array}{l}\text { a cleaner environment } \\
\text { environmental stewardship } \\
\text { environmental concerns in business operations }\end{array}$ \\
\hline $\begin{array}{c}\text { The social } \\
\text { dimension }\end{array}$ & $\begin{array}{c}\text { The relationship } \\
\text { between business } \\
\text { and society }\end{array}$ & $\begin{array}{l}\text { contribute to a better society } \\
\text { integrate social concerns in their business } \\
\text { operations } \\
\text { consider the full scope of their impact on } \\
\text { communities }\end{array}$ \\
\hline
\end{tabular}


International Journal of Heritage, Tourism and Hospitality Vol. (12), No. (3/2) Special issue on papers of the $11^{\text {th }}$ ICTH (2018) organized by Faculty of Tourism and Hotels, Fayoum University

\begin{tabular}{|c|c|l|}
\hline $\begin{array}{c}\text { The economic } \\
\text { dimension }\end{array}$ & $\begin{array}{c}\text { Socio-economic or } \\
\text { financial aspects, } \\
\text { including } \\
\text { describing CSR in } \\
\text { terms of a business } \\
\text { 'business } \\
\text { operations' }\end{array}$ & $\begin{array}{l}\text { Contribute to economic development' } \\
\text { Preserving the profitability' } \\
\text { Business operations }\end{array}$ \\
\hline $\begin{array}{c}\text { The } \\
\text { stakeholder } \\
\text { dimension }\end{array}$ & $\begin{array}{c}\text { Stakeholders or } \\
\text { stakeholder groups }\end{array}$ & $\begin{array}{l}\text { interaction with their stakeholders' } \\
\text { how organizations interact with their employees, } \\
\text { suppliers, customers and communities' } \\
\text { treating the stakeholders of the firm }\end{array}$ \\
\hline $\begin{array}{c}\text { The } \\
\text { voluntariness } \\
\text { dimension }\end{array}$ & $\begin{array}{c}\text { Actions not } \\
\text { prescribed by law }\end{array}$ & $\begin{array}{l}\text { based on ethical values' } \\
\text { Beyond legal obligations' voluntary. }\end{array}$ \\
\hline
\end{tabular}

Source: Dahlsrud (2008).

Managers now identify CSR and sustainability as "essential" for strategic operations, innovations, and talent management (Kiron, et al., 2013; Price Water House Coopers or PwC, 2011). Although the implementation of CSR activities often comes simply in the pursuit of a competitive advantage for companies and not because of a basic ethical obligation and doing what is right and reasons for participation in these activities are still different from company to another. Nevertheless, Hess (2008) argues that moral obligation should be the primary and main objective of CSR.

Recently, the global competition among companies has increased sharply, which has led to the need to discover the local markets accurately to meet the needs, so as not to find themselves in a bad position, which lose the competitive advantage that it was striving to achieve (Egels-Zandén, 2017).

CSR programs may include a wide range of interests, involving not only stakeholders but also employees, shareholders, consumers, government, society and the environment, as well as groups such as suppliers and trade unions business partners and even competitors (Ortas et al., 2015).

Local consumers usually value global brands and view them with respect and trust even though they pose a threat to society. This threat is the difference between cultures, especially those that appeal to local consumers in our society, leading to the loss of cultural identity. From this point, CSR practices have emerged as one of the policies used to narrow the gap between the culture and attitudes of these companies and the local community (Ismail et al., 2012).

Consumers' reaction to organizations' responsible behavior is an imperative incentive for firms to engage in CSR (Hartmann, 2011).

Lev et al., (2010) indicated in their investigation that "the potential positive impact of CSR on customer satisfaction and sales holds especially for firms in sectors where not the government or other firms but individual consumers are the predominant customers as those are highly sensitive to public perception". 
International Journal of Heritage, Tourism and Hospitality Vol. (12), No. (3/2) Special issue on papers of the $11^{\text {th }}$ ICTH (2018) organized by Faculty of Tourism and Hotels, Fayoum University

Figure 1. Examples of CSR activities

thit Starbucks Partners costarbucksprtnrs - Feb 1

February partners have a special place in

our hearts!

Happy partner anniversary to all the

February partners!

Chipotle and Intermarche - The Inglorious Fruit and Vegetable

\section{Food waste statistics are nothing but shocking.}

What is McDonald's corporate social responsibility (CSR) policy?"

We take our social responsibilities very seriously. For example, we're always looking for ways to reduce, reuse and recycle in our restaurants and across our whole business. For example, we use low energy LED light bulbs, energy saving equipment and waterless urinals, and recycle used cooking oil into biodiesel to fuel more than half of our delivery trucks. We also recycle the cardboard boxes used in more than $89 \%$ of our restaurants, and more than $85 \%$ of our packaging is made from renewable resources. We know that every little bit helps.

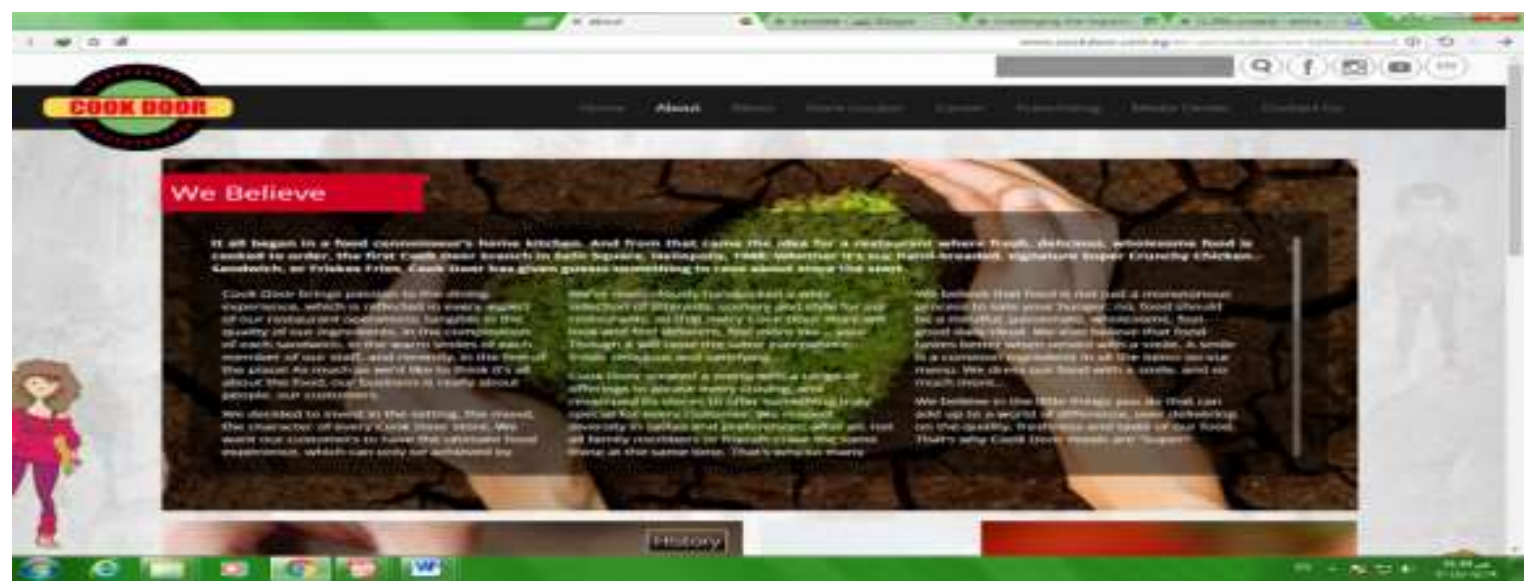

Local restaurant brands differ in critical ways from large enterprises. They tend to be owner managed, internally financed, limited with respect to financial, personal and time resources, strongly implanted in the local community (Fassin, 2008; Jenkins, 2009; Russo and Perrini, 2009; Allet, 2017). Those deviations from large enterprises are not without an impact on the CSR approach. Most of local brands are rather active with respect to CSR; however, their involvement differs and may not be measurable in the same way and to the same extent as for large (multinational) enterprises (Russo and Tencati, 2009; Walther et al., 2010; Baumann-Pauly, et al., 2013). 


\section{Materials and Methodology}

The field of study was accomplished through self-administered questionnaire, which includes studying the gap between the global and local restaurants chains. The questionnaire design prepared for this study is based on a comprehensive literature review. It is translated from English into Arabic. Open ended questions as well as the five-level Likert scale ranging from 1 " was Strongly disagree agree" to 5 "was strongly " was used to design the questionnaires form. The questionnaire is divided into 8 main questions. The self-administrated questionnaire was established in order to investigate the QSRs' Managers in regard to the CSR level and activities in QSRs.

Pilot study conducted in this study was on September, 2017. The survey was done through social media (face book, e-mails), telephone calls, the internet and field visits. Moreover, to ensure that the survey was well designed and easily understood by potential respondents, to examine the reliability and validity of the research tools as well as to develop and refine measure of the questions, questionnaire was reviewed by some academic scholars to establish their relevance, clarity and understanding. Some modifications were suggested and then were implemented.

Questionnaire was then pre-tested in order to investigate the respondent's understanding of scale items and to identify also any issues that are complex or confusing in order to develop appropriate scale items to ensure the validity and reliability of the research. For this purpose, a self-administered questionnaire was distributed to a sample of resort employees. 30 forms were distributed to respondents who were asked to complete them. Only 23 of the completed forms were valid which represents $76 \%$ rate of response.

Questionnaire distributed to the QSRs' Managers through the internet (Google drive, restaurant mails) and personal meetings in the period of October 2017 to February 2018. The total numbers of expected questionnaires were (200), only (150) questionnaires were done correctly and ready to be statistically analyzed by (75\%). The main purpose of this questionnaire was to evaluate the participations regarding the CSR to increase CSR in QSRs. the results obtained from the valid forms which statistically analyzed by using SPSS version 20.

\section{Study Instrument reliability}

For all scales, Cronbach's Alpha reliability was computed and the tests showed that the reliability coefficients for all the instruments were above 0.98 , which indicates that the instrument is reliable for being used. Cronbach's alpha for all survey instruments is shown in table (1) as follows:

Table 1: Reliability Statistics

\begin{tabular}{|c|c|c|}
\hline Cronbach's Alpha & No. of Items & No of Item questionnaire \\
\hline .980 & 47 & 150 \\
\hline
\end{tabular}

\section{Results and Discussions}

The responses obtained from the questionnaire are shown as follows:

The managers' awareness of CSR

The managers were asked about the CSR. The majority of the managers in the investigated restaurants $(62 \%)$ mentioned that they know the (CSR). while, some of the managers in the investigated restaurants (38\%) mentioned that they don't know about (CSR).

\section{The managers ' perceptions regarding the proper definition of CSR}

The managers were asked about the proper definition of CSR. The majority of the managers in the investigated restaurants $(49.3 \%)$ mentioned that the proper definition is 
International Journal of Heritage, Tourism and Hospitality Vol. (12), No. (3/2) Special issue on papers of the $11^{\text {th }}$ ICTH (2018) organized by Faculty of Tourism and Hotels, Fayoum University

Provide care through employment and with the same percentage Supporting and strengthening new laws and legislations.

Table 2: The managers ' perceptions regarding the proper definition of CSR

\begin{tabular}{|c|l|c|c|c|c|}
\hline No. & \multicolumn{2}{|c|}{ yes } & \multicolumn{2}{c|}{ No } \\
\cline { 2 - 6 } & \multicolumn{1}{|c|}{ Freq } & $\%$ & Freq & $\%$ \\
\hline 1 & $\begin{array}{l}\text { The chain should take into account the interests of } \\
\text { society in making business decisions }\end{array}$ & 35 & 23.3 & 115 & 76.7 \\
\hline 2 & $\begin{array}{l}\text { Maximize profits and serve the interests of } \\
\text { investors }\end{array}$ & 70 & 46.7 & 80 & 53.3 \\
\hline 3 & Sacrifice some profit for doing the right thing & 45 & 30.0 & 105 & 70.0 \\
\hline 4 & Provide care through employment & 74 & 49.3 & 76 & 50.7 \\
\hline 5 & $\begin{array}{l}\text { Supporting and strengthening new laws and } \\
\text { legislations }\end{array}$ & 74 & 49.3 & 76 & 50.7 \\
\hline 6 & $\begin{array}{l}\text { Support initiatives that serve the community } \\
\text { directly and not directly benefit shareholders }\end{array}$ & 55 & 36.7 & 95 & 63.3 \\
\hline
\end{tabular}

The managers' perceptions regarding the application level of the social responsibility activities in the restaurants chains; As well as, the Level of importance.

This question was designed to investigate the managers' perceptions concerning the social responsibility activities and rank this items according to their importance from the respondents' point of view/ and then arrange them according to their level in restaurants' chains. Regarding the social responsibility activities Table (3) shows the Importance and restaurants application.

Towards ranking the main group factors of the importance of social responsibility activities as well as their levels in the restaurants chains as showed in table (3), the results showed that:

Regarding the importance of social responsibility activities the most important factors of social responsibility activities:

Providing educational grants was the 1 st effect ranking position with mean (4.70). This

result indicates that educational grants are very important. Behavioral awareness campaigns were the 2 nd ranking positions mean (4.44). This result reflects the importance of awareness campaigns. Regarding the 3rd importance ranking position mean (4.39) was offering jobs to reduce unemployment. This shows the effect of reduce unemployment. In the 4th position was Support human rights, with average (4.44). This assured the effect of human rights. Concerning the 5th effect ranking mean (4.20) was regarding agree with that

Support small businesses and businesses. This result indicates that support small businesses are important. This agreed with Kiron, et al., (2013).

Table 3: the applicate level vs the level of importance of the social responsibility activities in the restaurants chains

\begin{tabular}{|c|l|c|c|c|c|}
\hline \multirow{2}{*}{ No. } & activity & \multicolumn{2}{|c|}{$\begin{array}{c}\text { Level of } \\
\text { applications }\end{array}$} & \multicolumn{2}{c|}{$\begin{array}{c}\text { Level of } \\
\text { importance }\end{array}$} \\
\cline { 2 - 6 } & \multicolumn{1}{|c|}{ Mean } & Rank & Mean & Rank \\
\hline 1 & Offering jobs to reduce unemployment & 4.4800 & 1 & 4.3933 & 3 \\
\hline 2 & Support small businesses and businesses & 2.3133 & 10 & 4.2000 & 5 \\
\hline 3 & Anti-smoking campaigns & 2.1000 & 12 & 2.5400 & 15 \\
\hline 4 & Support charities & 3.6400 & 5 & 3.5733 & 9 \\
\hline 5 & $\begin{array}{l}\text { Provide training and employment } \\
\text { opportunities for people with motor }\end{array}$ & 4.2933 & 2 & 2.8400 & 14 \\
\hline
\end{tabular}


International Journal of Heritage, Tourism and Hospitality Vol. (12), No. (3/2) Special issue on papers of the $11^{\text {th }}$ ICTH (2018) organized by Faculty of Tourism and Hotels, Fayoum University

\begin{tabular}{|c|l|c|c|c|c|}
\hline & disabilities & & & & \\
\hline 6 & Support and rehabilitation of orphans & 3.7133 & 4 & 1.2133 & 16 \\
\hline 7 & $\begin{array}{l}\text { Provide educational and professional } \\
\text { programs for women }\end{array}$ & 1.9467 & 13 & 3.6333 & 8 \\
\hline 8 & Medical Support Programs & 3.9333 & 3 & 3.6400 & 7 \\
\hline 9 & Food programs for the needy & 2.2133 & 11 & 3.2867 & 11 \\
\hline 10 & Support human rights & 1.1667 & 16 & 4.4400 & 4 \\
\hline 11 & Developing the state infrastructure & 1.4400 & 15 & 3.2667 & 12 \\
\hline 12 & Health awareness campaigns & 1.9333 & 14 & 3.1733 & 13 \\
\hline 13 & Environmental campaigns & 3.0333 & 7 & 3.4400 & 10 \\
\hline 14 & Traffic awareness campaigns & 2.9667 & 8 & 4.1533 & 6 \\
\hline 15 & Providing educational grants & 3.6067 & 6 & 4.7000 & 1 \\
\hline 16 & Behavioral awareness campaigns & 2.8000 & 9 & 4.4467 & 2 \\
\hline
\end{tabular}

Regarding the level of applications of social responsibility activities the highest level of applications were:

Offering jobs to reduce unemployment was the 1st Level of applications ranking position with mean (4.48). This result indicates that reduce unemployment is very important role of the restaurant chains. Provide training and employment opportunities for people with motor disabilities were the 2nd ranking position with mean (4.29). This result reflects the importance of training. Regarding the 3rd level of applications ranking position mean (4.29) was medical support programs. This shows the effect of medical support. In the 4th position was support and rehabilitation of orphans, with mean (3.71). Concerning the 5th Level of applications ranking mean (3.64) was regarding support charities. This agreed with Hartmann, (2011) and Puppim de Oliveira, and Jabbour (2017).

On a scale of 1 to 5 so that 1 is "strongly disagree" and 5 "strongly agree", please classify the following sentences for companies offering social responsibility programs?

This question was designed to investigate the managers' perceptions concerning the companies offering social responsibility programs. Towards managers' perceptions regarding companies offering social responsibility programs as showed in table (4), the results showed that: some of the respondents were "Strongly agree" with companies that Gain the loyalty of its employees by (47\%); and "agree" by the same percentage (47\%) with companies that have both a good work ethics and Reflect a positive image in society. Moreover, some of the respondents were "Neutral" with companies that Have customer satisfaction and obtain the confidence of customers who deal with them by (44\%), as well as, Adopting a strong relationship and loyalty relationship with its customers by (38\%).

Table 4: Managers' perceptions regarding companies offering social responsibility

\begin{tabular}{|c|c|c|c|c|c|c|c|c|c|c|c|}
\hline \multicolumn{12}{|c|}{ programs } \\
\hline & & \multicolumn{2}{|c|}{ 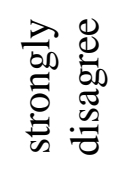 } & \multicolumn{2}{|c|}{ 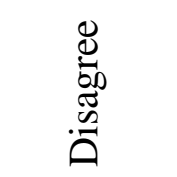 } & \multicolumn{2}{|c|}{ 苛 } & \multicolumn{2}{|c|}{ 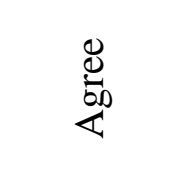 } & \multicolumn{2}{|c|}{ 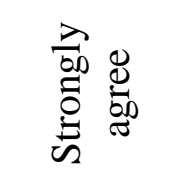 } \\
\hline \multirow[t]{2}{*}{ No } & \multirow[t]{2}{*}{ Factor } & \multicolumn{2}{|c|}{1} & \multicolumn{2}{|c|}{2} & \multicolumn{2}{|c|}{3} & \multicolumn{2}{|c|}{4} & \multicolumn{2}{|c|}{5} \\
\hline & & $\begin{array}{l}\text { Fr } \\
\text { eq }\end{array}$ & $\%$ & Freq & $\%$ & Freq & $\%$ & Freq & $\%$ & Freq & $\%$ \\
\hline 1 & $\begin{array}{c}\text { Have a good work } \\
\text { ethics }\end{array}$ & 5 & 3 & 20 & 13 & 25 & 17 & 70 & 47 & 30 & 20 \\
\hline
\end{tabular}


International Journal of Heritage, Tourism and Hospitality Vol. (12), No. (3/2) Special issue on papers of the $11^{\text {th }}$ ICTH (2018) organized by Faculty of Tourism and Hotels, Fayoum University

\begin{tabular}{|c|c|c|c|c|c|c|c|c|c|c|c|}
\hline 2 & $\begin{array}{c}\text { Obtain the confidence } \\
\text { of customers who deal } \\
\text { with them }\end{array}$ & 30 & 2 & 54 & 36 & 66 & 44 & 0 & 0 & 0 & 0 \\
\hline 3 & $\begin{array}{c}\text { Reflect a positive } \\
\text { image in society }\end{array}$ & 30 & 2 & 20 & 13 & 30 & 20 & 70 & 47 & 0 & 0 \\
\hline 4 & $\begin{array}{c}\text { Adopting a strong } \\
\text { relationship and } \\
\text { loyalty relationship } \\
\text { with its customers }\end{array}$ & 15 & 1 & 18 & 12 & 57 & 38 & 28 & 19 & 32 & 21 \\
\hline 5 & $\begin{array}{c}\text { Have customer } \\
\text { satisfaction }\end{array}$ & 10 & 7 & 14 & 9 & 66 & 44 & 18 & 12 & 42 & 28 \\
\hline 6 & $\begin{array}{c}\text { Gain the loyalty of its } \\
\text { employees }\end{array}$ & 5 & 3 & 20 & 13 & 25 & 17 & 30 & 20 & 70 & 47 \\
\hline
\end{tabular}

The managers' perception regarding the social responsibility activities in the restaurant chain

The managers were asked about the application of social responsibility activities in the restaurants chains. The majority of the managers in the investigated restaurants $(59 \%)$ mentioned that they excellently implicate the (CSR). And some of them (28\%) their chains have a good application for the (CRS). while, few of the managers in the investigated restaurants $(13 \%)$ mentioned that the level of their chains are poor in (CSR).

The managers' perception concerning the barriers facing them regarding CSR

The managers were asked about the barriers facing the management regarding CSR in their restaurants chains. The majority of the managers in the investigated local restaurants chains mentioned that, they have many barriers such: lack of capital and general resources (for example, human resources and financial resources), lack of understanding of environmental problems, lack of employee awareness ,lack of access to appropriate technology and lack of skills and relatively low level of research and development. On the other hand, the majority of the managers in the investigated global restaurants chains mentioned that, they have many barriers but they are suffering mainly form lack of welltrained human resources.

Prior to tests the reliability of each of the items used in this study. Reliability judges the degree to which measures are free from error, hence, yielding consistent results (Cuesta and Valor, 2013; Klettner, et al., 2014). Means and standard deviation in table (5) used to measure the reliability:

Table 5: scale items of CSR in QSRs

\begin{tabular}{|c|c|c|c|}
\hline Code & Factor & Mean & $\begin{array}{c}\text { Std. } \\
\text { Deviation }\end{array}$ \\
\hline chain & & 1.3333 & .47298 \\
\hline a1 & Have you ever heard of (CSR) & 1.3800 & .48701 \\
\hline a21 & $\begin{array}{l}\text { The chain should take into account the interests of } \\
\text { society in making business decisions }\end{array}$ & 1.7667 & .42437 \\
\hline a22 & $\begin{array}{l}\text { Maximize profits and serve the interests of } \\
\text { investors }\end{array}$ & 1.5333 & .50056 \\
\hline $\mathrm{a} 23$ & Sacrifice some profit for doing the right thing & 1.7000 & .45979 \\
\hline $\mathrm{a} 24$ & Provide care through employment & 1.5067 & .50163 \\
\hline a25 & $\begin{array}{l}\text { Supporting and strengthening new laws and } \\
\text { legislations }\end{array}$ & 1.5067 & .50163 \\
\hline $\mathrm{a} 26$ & Support initiatives that serve the community & 1.6333 & .48351 \\
\hline
\end{tabular}


International Journal of Heritage, Tourism and Hospitality Vol. (12), No. (3/2) Special issue on papers of the $11^{\text {th }}$ ICTH (2018) organized by Faculty of Tourism and Hotels, Fayoum University

\begin{tabular}{|c|c|c|c|}
\hline & directly and not directly benefit shareholders & & \\
\hline ha2 & Average & 1.6078 & .42046 \\
\hline a31 & Offering jobs to reduce unemployment & 4.4800 & .66272 \\
\hline a32 & Support small businesses and businesses & 2.3133 & .79543 \\
\hline a33 & Anti-smoking campaigns & 2.1000 & .83345 \\
\hline a34 & Support charities & 3.6400 & 1.76954 \\
\hline a35 & $\begin{array}{l}\text { Provide training and employment opportunities for } \\
\text { people with motor disabilities }\end{array}$ & 4.2933 & 1.02024 \\
\hline a36 & Support and rehabilitation of orphans & 3.7133 & 1.40630 \\
\hline a37 & $\begin{array}{l}\text { Provide educational and professional programs for } \\
\text { women }\end{array}$ & 1.9467 & .86534 \\
\hline a38 & Medical Support Programs & 3.9333 & 1.46396 \\
\hline a39 & Food programs for the needy & 2.2133 & 68136 \\
\hline $\mathrm{a} 310$ & Support human rights & 1.1667 & .37393 \\
\hline $\mathrm{a} 311$ & Developing the state infrastructure & 1.4400 & .63963 \\
\hline a312 & Health awareness campaigns & 1.9333 & .90240 \\
\hline a313 & Environmental campaigns & 3.0333 & 1.47651 \\
\hline $\mathrm{a} 314$ & Traffic awareness campaigns & 2.9667 & 1.36798 \\
\hline $\mathrm{a} 315$ & Providing educational grants & 3.6067 & 1.80936 \\
\hline $\mathrm{a} 316$ & Behavioral awareness campaigns & 2.8000 & 1.22611 \\
\hline ha3a & Average & 2.8488 & .95465 \\
\hline a41 & Have a good work ethics & 3.6667 & 1.04699 \\
\hline a42 & $\begin{array}{l}\text { Obtain the confidence of customers who deal with } \\
\text { them }\end{array}$ & 2.2400 & .76571 \\
\hline $\mathrm{a} 43$ & Reflect a positive image in society & 2.9333 & 1.18529 \\
\hline $\mathrm{a} 44$ & $\begin{array}{l}\text { Adopting a strong relationship and loyalty } \\
\text { relationship with its customers }\end{array}$ & 3.2933 & 1.21813 \\
\hline a45 & Have customer satisfaction & 3.4533 & 1.18484 \\
\hline $\mathrm{a} 46$ & Gain the loyalty of its employees & 3.9333 & 1.21327 \\
\hline ha4 & Average & 3.2533 & 1.04463 \\
\hline a51 & Offering jobs to reduce unemployment & 4.3933 & .80182 \\
\hline a52 & Support small businesses and businesses & 4.2000 & .75084 \\
\hline a53 & Anti-smoking campaigns & 2.5400 & .61992 \\
\hline a54 & Support charities & 3.5733 & 1.73533 \\
\hline a55 & $\begin{array}{l}\text { Provide training and employment opportunities for } \\
\text { people with motor disabilities }\end{array}$ & 2.8400 & 1.18197 \\
\hline a56 & Support and rehabilitation of orphans & 1.2133 & .41103 \\
\hline a57 & $\begin{array}{l}\text { Provide educational and professional programs for } \\
\text { women }\end{array}$ & 3.6333 & 1.82237 \\
\hline a58 & Medical Support Programs & 3.6400 & 1.69990 \\
\hline a59 & Food programs for the needy & 3.2867 & .73582 \\
\hline a510 & Support human rights & 4.4400 & .75512 \\
\hline a511 & Developing the state infrastructure & 3.2667 & .63104 \\
\hline a512 & Health awareness campaigns & 3.1733 & .77500 \\
\hline a513 & Environmental campaigns & 3.4400 & .49805 \\
\hline a514 & Traffic awareness campaigns & 4.1533 & .79205 \\
\hline a515 & Providing educational grants & 4.7000 & .45979 \\
\hline a516 & Behavioral awareness campaigns & 4.4467 & .67094 \\
\hline
\end{tabular}


International Journal of Heritage, Tourism and Hospitality Vol. (12), No. (3/2) Special issue on papers of the $11^{\text {th }}$ ICTH (2018) organized by Faculty of Tourism and Hotels, Fayoum University

\begin{tabular}{|c|l|c|c|}
\hline ha5 & Average & 3.5587 & .77784 \\
\hline a6 & $\begin{array}{l}\text { The managers' perception regarding the social } \\
\text { responsibility activities in the restaurant chain }\end{array}$ & 2.4533 & .71968 \\
\hline
\end{tabular}

Exploring the gap between the global and local chain in accordance to CSR application in QSRs

The Mann-Whitney U-test was used in this study to compare between the global chain and the local chain of CSR in QSRs from the management point of view in order to find out if there is a significant difference between them in terms of the CSR. The following tables and figures handle this issue:

There is a statistically significant difference between the two groups in terms of the majority of the scale variables. But, there is no significant difference among the two groups in terms of support human rights. Mean score was used also to determine which group is higher. The Mann-Whitney $U$ test revealed a statistically significant difference between the results in the Global chain and the Local chain of manage the CSR in QSRs in terms of all the factors such as : offering jobs to reduce unemployment, support small businesses and businesses, anti-smoking campaigns, support charities, provide training and employment opportunities for people with motor disabilities, support and rehabilitation of orphans, provide educational and professional programs for women and medical support programs.

Table 6: A summary of the mann-whitey u test between the global chain and the local chain in accordance to the application of CSR. (N 150)

\begin{tabular}{|c|c|c|c|c|}
\hline$\frac{\tilde{\theta}}{0}$ & The importance and the application & 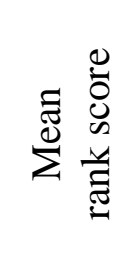 & 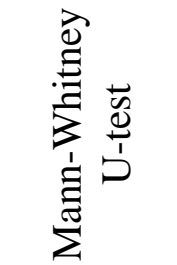 & 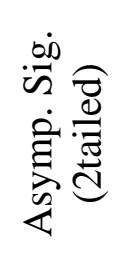 \\
\hline \multirow[t]{2}{*}{ a31 } & Global chain & 84.38 & \multirow[t]{2}{*}{123.000} & \multirow[t]{2}{*}{$.000^{*}$} \\
\hline & Local chain & 57.74 & & \\
\hline \multirow[t]{2}{*}{ a32 } & Global chain & 78.37 & \multirow[t]{2}{*}{902.500} & \multirow[t]{2}{*}{$.000 *$} \\
\hline & Local chain & 69.76 & & \\
\hline \multirow[t]{2}{*}{ a33 } & Global chain & 99.50 & \multirow[t]{2}{*}{1605.500} & \multirow[t]{2}{*}{$.000^{*}$} \\
\hline & Local chain & 27.50 & & \\
\hline \multirow[t]{2}{*}{ a34 } & Global chain & 100.50 & \multirow[t]{2}{*}{1141.500} & \multirow[t]{2}{*}{$.000 *$} \\
\hline & Local chain & 25.50 & & \\
\hline \multirow[t]{2}{*}{ a35 } & Global chain & 99.86 & \multirow[t]{2}{*}{2453.500} & \multirow[t]{2}{*}{$.000 *$} \\
\hline & Local chain & 26.78 & & \\
\hline \multirow[t]{2}{*}{ a36 } & Global chain & 100.50 & \multirow[t]{2}{*}{2409.000} & \multirow[t]{2}{*}{$.000 *$} \\
\hline & Local chain & 25.50 & & \\
\hline \multirow[t]{2}{*}{ a37 } & Global chain & 98.00 & \multirow[t]{2}{*}{2890.500} & \multirow[t]{2}{*}{$.000^{*}$} \\
\hline & Local chain & 30.50 & & \\
\hline \multirow[t]{2}{*}{ a38 } & Global chain & 100.50 & \multirow[t]{2}{*}{1130.500} & \multirow[t]{2}{*}{$.000 *$} \\
\hline & Local chain & 25.50 & & \\
\hline \multirow[t]{2}{*}{ a39 } & Global chain & 88.30 & \multirow[t]{2}{*}{1634.500} & \multirow[t]{2}{*}{$.000 *$} \\
\hline & Local chain & 49.90 & & \\
\hline \multirow[t]{2}{*}{ a310 } & Global chain & 78.00 & \multirow[t]{2}{*}{481.500} & \multirow[t]{2}{*}{$.123^{*}$} \\
\hline & Local chain & 70.50 & & \\
\hline
\end{tabular}


International Journal of Heritage, Tourism and Hospitality Vol. (12), No. (3/2) Special issue on papers of the $11^{\text {th }}$ ICTH (2018) organized by Faculty of Tourism and Hotels, Fayoum University

\begin{tabular}{|c|c|c|c|c|}
\hline \multirow[t]{2}{*}{ a311 } & Global chain & 82.10 & \multirow[t]{2}{*}{1161.500} & \multirow[t]{2}{*}{$.002 *$} \\
\hline & Local chain & 62.30 & & \\
\hline \multirow[t]{2}{*}{ a312 } & Global chain & 96.50 & \multirow[t]{2}{*}{1624.500} & \multirow[t]{2}{*}{$.000^{*}$} \\
\hline & Local chain & 33.50 & & \\
\hline \multirow[t]{2}{*}{ a313 } & Global chain & 100.50 & \multirow[t]{2}{*}{198.000} & \multirow[t]{2}{*}{$.000 *$} \\
\hline & Local chain & 25.50 & & \\
\hline \multirow[t]{2}{*}{ a314 } & Global chain & 100.50 & \multirow[t]{2}{*}{101.500} & \multirow[t]{2}{*}{$.000 *$} \\
\hline & Local chain & 25.50 & & \\
\hline \multirow[t]{2}{*}{ a315 } & Global chain & 100.50 & \multirow[t]{2}{*}{148.000} & \multirow[t]{2}{*}{$.000 *$} \\
\hline & Local chain & 25.50 & & \\
\hline \multirow[t]{2}{*}{ a316 } & Global chain & 100.50 & \multirow[t]{2}{*}{228.000} & \multirow[t]{2}{*}{$.000 *$} \\
\hline & Local chain & 25.50 & & \\
\hline \multirow[t]{2}{*}{ ha3a } & Global chain & 100.50 & \multirow[t]{2}{*}{.000} & \multirow[t]{2}{*}{$.000 *$} \\
\hline & Local chain & 25.50 & & \\
\hline
\end{tabular}

Table (7) showed the correlation matrix among CSR activities in QSRs. The results revealed that there were significant correlations among QSRs activities and the type of QSRs global and local chains. The results showed that there were strong correlations between all proposed relation in the conceptual hypotheses, with (r) values ranging from ($.873)$ to $(.989)(\mathrm{p}<.01) * *$. Correlation was significant at the 0.01 level (2-tailed). Based on the results of Pearson correlation analysis which represent proposed linear relationship, all the research hypotheses were fully supported.

Table 7: summary of correlation analysis and hypotheses testing

\begin{tabular}{|c|c|c|c|c|c|c|}
\hline & chain & a1 & ha2 & ha3a & ha4 & ha5 \\
\hline chain & 1 & & & & & \\
\hline \multirow[t]{2}{*}{$\mathrm{a} 1$} & $.758 * *$ & 1 & & & & \\
\hline & .000 & & & & & \\
\hline \multirow[t]{2}{*}{ ha2 } & $.364 * *$ & $.607 * *$ & 1 & & & \\
\hline & .000 & .000 & & & & \\
\hline \multirow[t]{2}{*}{ ha3a } & $-.899-* *$ & $-.556-* *$ & .013 & 1 & & \\
\hline & .000 & .000 & .874 & & & \\
\hline \multirow[t]{2}{*}{ ha4 } & $-.833-* *$ & $-.463-* *$ & $.164 *$ & $.969 * *$ & 1 & \\
\hline & .000 & .000 & .045 & .000 & & \\
\hline \multirow[t]{2}{*}{ ha5 } & $-.873-* *$ & $-.537-* *$ & .060 & $.989 * *$ & $.986 * *$ & 1 \\
\hline & .000 & .000 & .462 & .000 & .000 & \\
\hline
\end{tabular}

\section{Summary, Conclusion and Recommendations}

Researchers have never before addressed CSR in the form of an exploratory study of what is applied in global and local restaurant chains in Egypt. This research is also new in terms of exploring what is actually implemented and what programs should be implemented according to the importance of the elements showed in the methodology. This indicates the novelty of this study and the importance of the results reached.

One of the main findings of the research is that the size of the company should not be a fundamental criterion when trying to understand or predict CSR. Examples of Global CSR activities in the small business community and local initiatives include scholarship programs (cross-education grants) between international restaurant chains and public universities to ensure job opportunities for students as well as university education. The companies that do this are developing the local community, in the sense that they 
International Journal of Heritage, Tourism and Hospitality Vol. (12), No. (3/2)

Special issue on papers of the $11^{\text {th }}$ ICTH (2018) organized by Faculty of Tourism and Hotels, Fayoum University

demonstrate that CSR includes the actions that companies undertake to contribute to a better society, locally and globally.

The previous finding goes against the point of view of Juholin (2004) in that the focus on large companies and a certain type of CSR activities contributes to narrowing the horizon of CSR.

Actually CSR initiatives have become a core part of business activities in the food sector, in particular for enterprises with high-value consumer brands (Dlott et al., 2006). The success of organizations in their role in social responsibility depends primarily on their commitment to three criteria: Respect and responsibility, in the sense of respect for the company's internal environment (workers), the external environment (community members), Community support, and Protecting the environment, both in terms of compliance with the company's product offering to the community with the environment, or in terms of the initiative to provide the environment, improve environmental conditions in the community and address the various environmental problems. The majority of the managers in the investigated restaurants (62\%) mentioned that they know the (CSR). The majority of the managers in the investigated restaurants (49.3\%) mentioned that the proper definition is Provide care through employment and with the same percentage Supporting and strengthening new laws and legislations. Providing educational grants was the 1st effect ranking position this result indicates that educational grants are very important. Behavioral awareness campaigns were the 2nd ranking positions. Offering jobs to reduce unemployment was the 1st Level of applications ranking position this result indicates that reduce unemployment is very important role of the restaurant chains. Provide training and employment opportunities for people with motor disabilities were the 2nd ranking position. Some of the respondents were "Strongly agree" with companies that Gain the loyalty of its employees; and "agree" with companies that have both a good work ethics and Reflect a positive image in society.

There is a statistically significant difference between the two groups in terms of the majority of the scale variables. But, there is no significant difference among the two groups in terms of support human rights. Mean score was used also to determine which group is higher. The Mann-Whitney $U$ test revealed a statistically significant difference between the results in the Global chain and the Local chain of manage the CSR in QSRs in terms of all the factors. The results showed that there were strong correlations between all proposed relations in the conceptual hypotheses.

\section{CSR Gap Model}

The CSR gap model is a model between the importance of CSR and the level of application of the QSRs in accordance to CSR management from the perspective of QSRs managers see table (8).

The aim of this model is to shed light on the gaps between the managers' perceptions regarding the CSR level of importance in QSRs versus the level of applications in order achieve the CSR At a better way.

Table 8: A Model of the CSR gap

\begin{tabular}{|c|c|c|c|c|c|c|c|}
\hline \multirow{2}{*}{$\dot{\mathbf{Z}}$} & Factors & \multicolumn{2}{|c|}{$\begin{array}{c}\text { Level of } \\
\text { importance }\end{array}$} & \multicolumn{2}{c|}{$\begin{array}{c}\text { Level of } \\
\text { applications }\end{array}$} & \multicolumn{2}{c|}{ The gap } \\
\cline { 3 - 8 } & Mean & $\begin{array}{c}\text { Ran } \\
\mathrm{k}\end{array}$ & Mean & $\begin{array}{c}\text { Ran } \\
\mathrm{k}\end{array}$ & level & Rank \\
\hline 1 & $\begin{array}{c}\text { Offering jobs to reduce } \\
\text { unemployment }\end{array}$ & 4.3933 & 3 & 4.4800 & 1 & -0.09 & 13 \\
\hline 2 & Support small & 4.2000 & 5 & 2.3133 & 10 & 1.89 & 2 \\
\hline
\end{tabular}


International Journal of Heritage, Tourism and Hospitality Vol. (12), No. (3/2) Special issue on papers of the $11^{\text {th }}$ ICTH (2018) organized by Faculty of Tourism and Hotels, Fayoum University

\begin{tabular}{|c|c|c|c|c|c|c|c|}
\hline & businesses & & & & & & \\
\hline 3 & $\begin{array}{l}\text { Anti-smoking } \\
\text { campaigns }\end{array}$ & 2.5400 & 15 & 2.1000 & 12 & 0.44 & 10 \\
\hline 4 & Support charities & 3.5733 & 9 & 3.6400 & 5 & -0.07 & 12 \\
\hline 5 & $\begin{array}{l}\text { Provide training and } \\
\text { employment } \\
\text { opportunities for people } \\
\text { with motor disabilities }\end{array}$ & 2.8400 & 14 & 4.2933 & 2 & -1.45 & 15 \\
\hline 6 & $\begin{array}{c}\text { Support and } \\
\text { rehabilitation of } \\
\text { orphans }\end{array}$ & 1.2133 & 16 & 3.7133 & 4 & -2.50 & 16 \\
\hline 7 & $\begin{array}{l}\text { Provide educational and } \\
\text { professional programs } \\
\text { for women }\end{array}$ & 3.6333 & 8 & 1.9467 & 13 & 1.69 & 4 \\
\hline 8 & $\begin{array}{c}\text { Medical Support } \\
\text { Programs }\end{array}$ & 3.6400 & 7 & 3.9333 & 3 & -0.29 & 14 \\
\hline 9 & $\begin{array}{l}\text { Food programs for the } \\
\text { needy }\end{array}$ & 3.2867 & 11 & 2.2133 & 11 & 1.07 & 9 \\
\hline 10 & Support human rights & 4.4400 & 4 & 1.1667 & 16 & 3.27 & 1 \\
\hline 11 & $\begin{array}{l}\text { Developing the state } \\
\text { infrastructure }\end{array}$ & 3.2667 & 12 & 1.4400 & 15 & 1.83 & 3 \\
\hline 12 & $\begin{array}{l}\text { Health awareness } \\
\text { campaigns }\end{array}$ & 3.1733 & 13 & 1.9333 & 14 & 1.24 & 6 \\
\hline 13 & $\begin{array}{l}\text { Environmental } \\
\text { campaigns }\end{array}$ & 3.4400 & 10 & 3.0333 & 7 & 0.41 & 11 \\
\hline 14 & $\begin{array}{c}\text { Traffic awareness } \\
\text { campaigns }\end{array}$ & 4.1533 & 6 & 2.9667 & 8 & 1.19 & 7 \\
\hline 15 & $\begin{array}{l}\text { Providing educational } \\
\text { grants }\end{array}$ & 4.7000 & 1 & 3.6067 & 6 & 1.09 & 8 \\
\hline 16 & $\begin{array}{c}\text { Behavioral awareness } \\
\text { campaigns }\end{array}$ & 4.4467 & 2 & 2.8000 & 9 & 1.65 & 5 \\
\hline
\end{tabular}

\section{Limitations And Future Research}

The limitation of the study is related to some other measurements of the size of the company (for example, the total asset value, sales volume, market capitalization, or market value of the series, especially global chains) were not investigated since they lay outside the scope of the present study which could be supplemented by future studies.

\section{References}

Allet, M, (2017). Mitigating Environmental Risks in Microenterprises: A Case Study from El Salvador. Business \& Society, 56, 57-91.

Amaeshi, M., Osuji,Onyeka,K and Nnodim,P. (2007). " CSR in Supply Chains of Global Brands: A Boundaryless Responsibility? Clarifications, Exceptions and Implications", Journal of Business Ethics. 81, 223-234.

Baumann-Pauly, D., Wickert, C., Spence, L., \& Scherer, A. G. (2013). Organizing CSR in small and large firms: Size matters. Journal of Business Ethics, 115, 693-705.

Carroll, B. and Shabana, M. (2010), "The Business Case for CSR: A Review of Concepts, Research and Practice", Global Journal of Management Reviews, 12 (1): 85-105. 
International Journal of Heritage, Tourism and Hospitality Vol. (12), No. (3/2)

Special issue on papers of the $11^{\text {th }}$ ICTH (2018) organized by Faculty of Tourism and Hotels, Fayoum University

Claver-Cortes, E., Molina-Azorin, F., Pereira-Moliner, J., Lopez-Gamero, D. (2007). "Environmental Strategies and their Impact on Hotel Performance". J. Sus. Tour. 15 (6), 663-679.

Cochran, P. (2007), “The Evolution of CSR”, Business Horizons, 50 (6), 449-54.

Cuesta, L., Valor, C., (2013). Evaluation of the Environmental, Social and Governance Information Disclosed by Spanish Listed Companies. Social Responsibility Journal, 9 (2), 220-240.

Dahlsrud, A. (2008). "How CSR is defined: An Analysis of 37 Definitions". CSR and Environmental Management, 15: 1-13.

Dlott, J., Gunders, D. and Arnold, A. (2006). "Sustainability Trends in the Agrifood Sector". Sure Harvest Briefing Paper. Soquel, UK: Sure Harvest.

Egels-Zandén, N. (2017). The Role of SMES In Global Production Networks: A Swedish SME's Payment of Living Wages at its Indian Supplier. Business \& Society, 56, 92129.

Fassin, Y. (2008). "SMEs and the Fallacy of Formalizing CSR". Business Ethics: A European Review, 17: 364-378.

Garay, L and Font, X. (2012). "Doing good to do well? CSR reasons, practices and impact in small and medium accommodation enterprises". Int. J. Hosp. Manage. 31 (2), 329337.

Hartmann, M. (2011). "CSR in the Food Sector". European Review of Agricultural Economics 38 (3) 297-324.

Hess, D. (2008). "The Three Pillars of Corporate Social Reporting as New Governance Regulation: Disclosure, Diablogue, and Development". Business Ethics Quarterly 18, 447-482.

Ismail, Z., Masood, S. and Mehmood, T. (2012). "Factors Affecting Consumer Preference of Global Brands over Local Brands", 2nd Global Conference on Social Science and Humanity. IACSIT Press, Singapore, 31.

Jenkins, H. (2009). "A Business Opportunity Mode of CSR for Small-and Medium Sized Enterprises". Business Ethics: A European Review, 18: 21-36

Kang, H., and Huh, C. (2010). "Impacts of Positive and Negative CSR Activities on Company Performance in the Hospitality Industry". Int. J. Hosp. Manage. 29, (1), 7282. Available from: "http://dx.doi.org/10.1016/j.ijhm.2009.05.006", [Accessed on 17 03- 2018].

Kiron, D., Kruschwitz, N., Reeves, M. and Goh, E. (2013). "The benefits of sustainabilitydriven innovation," MIT Sloan Management Review, 54 (2), 69-73.

Klettner, A., Clarke, T., Boersma, M., (2014). The Governance of Corporate Sustainability: Empirical Insights into the Development, Leadership, and Implementation of the Responsible Business Strategy, Journal of Business Ethics, 122 (1), 145-165.

Lee, P. (2008). "Review of the Theories of CSR: Its Evolutionary Path and the Road Ahead". Global Journal of Management Reviews, 10(1), 53-73.

Lee, S., Park, S.Y., (2009). "Do Socially Responsible Activities Help Hotels and Casinos Achieve their Financial Goals?" Int. J. Manage. 28(1) 105-112. Available from: "http://dx.doi.org/ 10.1016/j.ijhm.2008.06.003" ", [Accessed on 13-0-4- 2018].

Lev, B., Petrovits, C. and Radhakrishnan, S. (2010). "Is Doing Good Good for You? How Corporate Charitable Contributions Enhance Revenue Growth". Strategic Management Journal 31, 182-200. 
International Journal of Heritage, Tourism and Hospitality Vol. (12), No. (3/2)

Special issue on papers of the $11^{\text {th }}$ ICTH (2018) organized by Faculty of Tourism and Hotels, Fayoum University

Mishra, S and Suar, D. (2010). Does CSR Influence Firm Performance of Indian Companies? Journal of Business Ethics, 95 (4), 571-601.

Murillo, H and Martinek, J. (2009). "CSR Can Be Profitable. Available from: "https://www.stlouisfed.org", [Accessed on 10- - 04- 2018].

Ortas, E., Gallego-Alvarez, I and Etxeberria, A. (2015). Financial Factors Influencing the Quality of CSR and Environmental Management Disclosure: A Quantile Regression Approach. CSR and Environmental Management, 22, 362-380.

Park, Y and Levy E. (2014), "CSR: Perspectives of Hotel Frontline Employees". Global Journal of Contemporary Hospitality Management, vol. 26, Iss: 3 pp. 332-348.

Puppim de Oliveira, A and Jabbour, C. (2017). Environmental Management' Climate Change, CSR, and Governance in Clusters of Small Firms in Developing Countries: Towards an Integrated Analytical Framework. Business \& Society, 56, 130-151.

Price Water House Coopers. (2011), "Millennials at Work: Reshaping the workplace". Available from: "http://www.pwc.com/gx/en/managing-tomorrows-people/future-ofwork/download.jhtml ", [Accessed on 15 - 12- 2017].

Russo, A. and Perrini, F. (2009). "Investigating Stakeholder Theory and Social Capital: CSR in Large Firms and SMEs". Journal of Business Ethics, 91, 207-221.

Russo, A. and Tencati, A. (2009). "Formal vs. Informal CSR Strategies: Evidence from Italian Micro, Small, Medium-Sized, and Large Firm". Journal of Business Ethics, 85, 339-353.

Sila, I and , Ceka,K. (2017).The Impact of Environmental, Social and Governance Dimensions of CSR on Economic Performance: Australian Evidence. 9th International Conference on Theory and Application of Soft Computing, Computing with Words and Perception, ICSCCW 2017, 24-25 August 2017, Budapest, Hungary. Procedia Computer Science 120 (2017) 797-804.

Walther, M., Schenkel, M. and Schu“ssler, M. (2010). " CSR as Strategische Herausforderung für den Mittelstand. In: D. Kathan, P. Letmathe, K. Mark, R. Schulte, M. Tchouvakhina and F. Wallau (eds), Wertscho"pfungsmanagement im Mittelstand. Tagungsband des Forums der deutschen Mittelstandsforschung. Wiesbaden: Gabler Verlag/Springer Fachmedien Wiesbaden GmbH, pp.87-102.

Warsi, A and Nisa, S. (2017). "Food Retailing: Fast Food Industry", SSRN Electronic Journal. Available from: "https://www.researchgate.net/publication/228136941", [Accessed on 09-0-2- 2018].

Wood, D. (2010), "Measuring Corporate Social Performance: A Review", Global Journal of Management Reviews, 2 (1), 50-84.

Yin, J. (2017). Institutional Drivers for CSR in an Emerging Economy: A Mixed-Method Study of Chinese Business Executives. Business \& Society, 56, 672-704. 